\title{
PERAN NORMA SUBYEKTIF DAN MOTIVASI PENGUSAHA PADA KEPUTUSAN PEMBIAYAAN UTANG UKM
}

\author{
N. M. Suci \\ Jurusan Manajemen, Universitas Pendidikan Ganesha, Singaraja \\ e-mail: made.suci@undiksha.ac.id
}

\begin{abstract}
Abstrak
Penelitian ini bertujuan untuk menguji pengaruh norma subyektif pada keputusan utang pengusaha UKM baik secara langsung maupun melalui mediasi motivasi berprestasi pengusaha. Penelitian dilakukan pada UKM kerajinan tangan di Provinsi Bali dengan jumlah sampel 180 pengusaha yang ditentukan secara purposive sampling. Pengumpulan data dengan kuesioner kemudian dianalisis dengan SEM-PLS. Hasil penelitian ini bahwa 1) norma subyektif tidak berpengaruh terhadap keputusan hutang pengusaha UKM 2) motivasi berprestasi pengusaha berpengaruh positif dan signifikan terhadap keputusan hutang UKM, 3) norma sujektif tidak berpengaruh terhadap motivasi berprestasi pengusaha 6) prestasi Motivasi no memediasi pengaruh norma subyektif pengusaha terhadap keputusan utang konteks UKM
\end{abstract}

Kata kunci: norma subyektif pengusaha, motivasi pengusaha dan keputusan hutang

This study aims to examine the effect of subjective norm on debt decisions of SME entrepreneurs both directly and through mediation of the achievement motivation of entrepreneurs. The study was conducted on handicraft SMEs in Bali Province with a total sample of 180 entrepreneurs who were determined by purposive sampling.Data collection by questionnaire then analyzed by SEM-PLS. The results of this study that 1) subjective norm has no effect on the debt decisions of SME entrepreneur's 2) entrepreneur's achievement motivation has a positive and significant effect on SME debt decisions, 3)Sujective norm has no effect on entrepreneur achievement motivation 6) achievement motivation no mediates the influence of entrepreneur's subjective norm to the debt decisions of SME contexts

Keywords: entrepreneur's subjective norm, entrepreneur's motivation and debt decision

\section{Pendahuluan}

Pertumbuhan usaha pada UKM masih sangat rendah karena alasan klasik kurangnya kemampuan akses pengusaha terhadap sumber-sumber pembiayaan utang. Padahal, berbagai program pembinaan telah diberikan oleh pemerintah pusat dan daerah untuk meningkatkan kemampuan tersebut. Namun, studi Wengeldan Rodriguez (2006), Wilklundet al. (2003) menemukan bahwa rendahnya pertumbuhan usaha pada UKM justru karena perilaku pengusahanya. Perilaku pengusaha UKM cenderung menghindari sumber pembiayaan utang untuk menghindari risiko dan beban kerja yang tinggi. Oleh karena itu, perlu diketahui perilaku pengusaha dalam membiayai usahanya.

Temuan penelitian terdahulu tidak konsisten dalam menjelaskan keputusan pembiayaan utang UKM. Ketidak konsistenan karena hanya ditekankan pada karakteristik usaha dan demografi pengusaha tanpa mempertimbangkan aspek norma subyektif dan motivasi pengusahanya. Norma subyektif menyangkut keyakinan pengusaha terhadap dukungan dari orang-orang penting baginya dalam mengambil suatu keputusan. Orangorang penting yang dimaksud adalah anggota keluarga, rekan bisnis, teman dan pemerintah. Pertimbangan aspek norma subyektif dan motivasi pengusaha dalam menjelaskan keputusan pembiayaan pada UKM penting karena hal sangat berperan dalam mempengaruhi perilaku seseorang (Crothers et al., 2008). Prediksi ini didukung Mac An Bhaird (2010) bahwa ketidak konsistenan teori keuangan struktur modal dalam menjelaskan keputusan pembiayaan UKM karena tidak mempertimbangkan aspek-aspek non rasional dalam pengambilan keputusan keuangan tersebut. Padahal, UKM umumnya berlokasi di daerah pedesaan dan cenderung merupakan perusahaan keluarga sehingga kemungkinan 
besar aspek norma subyektif dan motivasi pengusaha mempengaruhi keputusan- keputusan bisnisnya.

Selain itu, norma subyektif telah terkonfirmasi mempengaruhi perilaku-perilaku tertentu pengusaha terutama dalam pemanfaatan sumber daya perusahaannya (Hoffmanet al.,2015;Setia-Atmajaet al.,2009). Bahkan Alleyne and Tracey (2011), Sharma dan Gupta (2011) menemukan bahwa norma subjektif sebagai predictor utama keputusan investasi seseorang. Berbeda dengan temuan Wijaya (2008) bahwa norma subyektif tidak berpengaruh pada terhadap keputusan-keputusan bisnis pengusaha baik secara langsung maupun melalui intensi berperilaku wirausaha. Ketidak konsistenan temuan empiris tersebut karena hanya mempertimbangkan norma-norma sosial saja tanpa norma-norma deskriptif padahaalnormadeskripsi mempunyai kemampuan prediksi yang lebih tinggi (Mannin,2009). Norma deskripstif menyangkut keberhasilan atau kegagalan orang-orang penting bagi pengusaha dalam pembiayaan utang akan mempengaruhi keputusan pembiayaan utang pengusaha UKM. Pengukuran norma subyektif menyangkut norma-norma social dan normanorma deskripsi diharapkan dapat meningkatkan kemampuan prediksinya dalam menjelaskan keputusan pembiayaan utang UKM

Pengusaha UKM diidentikkan dengan perilaku wirausaha dengan karakteristik mempunyai motivasi berprestasi yang tinggi (Abdulwahab dan Al-Damen, 2015). Oleh karena itu, motivasi berprestasi pengusaha diduga mempengaruhi keputusan-keputusan bisnisnya. Prediksi ini sesuai dengan temuan Wang et al. (2006), Shepherd dan Wiklund (2005) bahwa pengusaha dengan motivasi berprestasi yang tinggi cenderung lebih mempergunakan sumber pembiayaan utang.

Penelitian-penelitian terdahulu telah mengkonfirmasi bahwa motivasi berprestasi pengusaha mempengaruhi keputusan-keputusan bisnisnya (Wang et al., 2006; Shepherd dan Wiklund, 2005). Namun, belum ada studi yang mencoba menjelaskan bagaimana mekanisme mediasi motivasi berprestasi pengusaha pada pengaruh norma subyektif terhadap keputusan pembiayaan utang UKM. Penjelasan proses mediasi ini penting agar temuan yang dihasilkan lebih komprehensif dan ketika diterapkan dapat lebih bermanfaat (Chartieret al., 2009; MacKinnon, 2012).Selain itu, motivasi berprestasi pengusaha telah terkonfirmasi memediasi hubungan pada berbagai setting penelitian seperti: hubungan aspek kognitif dengan perilaku kreatif pengusaha (Mustikarini, 2013), ciri-ciri kepribadian pengusaha dengan kinerjanya (HalimdanZainal, 2015) Jadi semakin tinggi keyakinan adanya dukungan orang-orang penting serta perilaku aktual yang ditunjukkan orang-orang penting tersebut dalam pembiayaan usahanya mempengaruhi semakin tinggi motivasi berprestasi pengusaha dan semakin banyak mempergunakan sumber pembiayaan utang.

Norma subyektif merupakan salah satu komponen dari teori tindakan beralasan (Theory Reasoned Action/TRA) (Thorbjornsen et al., 2008). Teori ini mengasumsikan bahwa a) manusia melakukan sesuatu dengan cara yang masuk akal; b) manusia mempertimbangkan semua informasi yang ada; c) secara eksplisit maupun implicit manusia mempertimbangkan implikasi dari tindakannya (FishbeindanAzjen, 1975). Norma subyektif terdiri dari norma-norma sosial dan norma-norma deskriptif. Norma-normasosial menunjukkan keyakinan diri pengusahaterhadap dukungan, pendapat dan tekanan orangorang penting baginya dalam berperilaku tertentu (Makpotche et al., 2015) sedangkan norma-norma deskriptif merupakan perilaku aktual tertentu yang ditunjukkan orang-orang penting tersebut mempengaruhi keputusan seseorang.

Norma subyektif pengusaha mempengaruhi keputusan pembiayaan utang UKM karena sebagian besar merupakan perusahaan keluarga dan berlokasi di daerah pedesaan. Selain itu, walaupun tidak nampak secara jelas pengusaha UKM memiliki saling ketergantungan secara moril dan dukungan dalam menjalankan usahanya sehingga semakin tinggi norma subyektif pengusaha mendorongnya semakin banyak mempergunakan pembiayaan utang. Berdasarkan teori dan temuan empiris tersebut, dirumuskan hipotesis sebagai berikut.

$\mathrm{H}_{1}$ : Norma subyektif berpengaruh positif terhadap keputusan pembiayaan utang pada UKM. 
Motivasi merupakan proses psikologis yang mendorong seseorang untuk mencapai tujuan berperilaku atau alasan yang mendasari suatu perilaku (Guayet al., 2010). Motivasi merupakan suatu fungsi, proses dan tujuan akhir.Temuan Smith (2015) menunjukkan bahwa motivasi berprestasi mempunyai validitas dan reliabilitas yang tinggi dalam menjelaskan perilaku tertentu sehingga penting dipertimbangkan dalam merancang perubahan perilaku pengusaha dalam mengelola usahanya. Pengusaha dengan motivasi berprestasi yang tinggi akan mengerahkan segala daya dan upaya untuk mencapai kesuksesan usahanya dan menghindari kegagalan (Wang et al., 2006; Shepherd danWiklund (2005).

Selain itu, motivasi berprestasi pengusaha telah terkonfirmasi mempengaruhi perilaku dan kesuksesan bisnisnya (Collins et al., 2004). Pengukuran motivasi berprestasi pengusaha dapat dilakukan dengan metode kuesioner (self report) dan Thematic Apperception Test (TAT). Pengukuran dengan kuesioner dilakukan dengan menanyakan secara langsung pengusaha mengenai apa yang menjadi motivasi perilaku tertentu lebih dipilih pada situasi tertentu. Metode ini didasarkan pada asumsi bahwa motivasi berperilaku ditunjukkan secara langsung. Kenyataannya, manusia tidak selalu dapat dengan tepat dan sadar mengungkapkan alasan yang mendasari perilakunya dan terkadang mengungkapkan alasan yang lebih dari yang diduga (Nisbett dan Wilson, 1977). Namun demikian, metode kuesioner menunjukkan kegunaan yang baik dalam menilai motivasi seseorang dalam sejumlah penelitian empiris (Spangler, 1992). Pengukuran motivasi berprestasi pengusaha dengan Thematic Apperception Test (TAT) yaitu mengetahui motivasi seseorang dengan mengkonfrontasikannya dengan seperangkat gambar, selanjutnya menanyakan dan memintanya untuk menceritakan kembali kisah yang ada didalamnya. Pengukuran motivasi ini diperoleh melalui analisis isi secara sistematis dengan sistem penilaian khusus. Kekuatan prediksi pengukuran motivasi dengan model TAT ini, juga ditemukan baik (Spangler 1992).

Berdasarkan teori dan temuan empiris tersebut dirumuskan hipotesis sebagai berikut.

$H_{2:}$ Motivasi berprestasi pengusaha berpengaruh positif terhadap keputusan pembiayaan utang UKM.

Motivasi berprestasi merupakan motivasi intrinsik yang mendorong perilakutertentu lebih unggul daripada orang lain dan standar yang telah ditetapkan (Koestnerdan McClelland, 1990). Motivasi berprestasi dipengaruhi aspek pribadi dan lingkungan sosial seseorang (Culkin dan Smith, 2000), karena itu norma subyektif sebagai aspek pribadi diduga mempengaruhi motivasi berprestasi pengusaha dalam mengelola usahanya. Berdasarkan teori dan temuan empiris tersebut, semakin tinggi norma subyektif pengusaha, semakin tinggi pula motivasi berprestasinya dalam mengelola usaha sehingga dirumuskan hipotesis sebagai berikut.

$\mathrm{H}_{3}$ : norma subyektif berpengaruh positif terhadap motivasi berprestasi pengusaha UKM.

Motivasi merupakan proses psikologis yang mendorong seseorang untuk mencapai tujuan berperilaku (Guayet al., 2010). Motivasi sebagai proses yang timbul karena adanya rangsang dari faktor internal dan eksternal individu.Studi Taormina dan lao(2007) menemukan motivasi berprestasi merupakan motivasi instrinsik yang dipengaruhi faktor pribadi dan lingkungan sosial seseorang. Oleh karena itu, norma subyektif diduga mempengaruhi motivasi berprestasi pengusaha dan keputusan pembiayaan utang pengusaha UKM. Semakin tinggi norma subyektif pengusaha, semakin tinggi motivasi berprestasinya dan semakin banyak pengusaha mempergunakan sumber pembiyaaan utang. Berdasarkan teori dan temuan empiris tersebut maka dirumuskan hipotesis sebagai berikut.

$\mathrm{H}_{4}$ : Motivasi berprestasi pengusaha memediasi pengaruh norma subyektif terhadap keputusan pembiayaan utang UKM.

\section{Metode}

Penelitian eksplanasi ini bertujuan untuk menjelaskan perilaku pembiayaan utang pengusaha UKM dengan menguji pengaruh norma subyektif pengusaha terhadap keputusan pembiayaan utangnya baik secara langsung maupun melalui mediasi motivasi berprestasi 
pengusahanya. Penelitiandilakukan pada pengusaha UKM sektor industri kerajinan di Provinsi Bali karena pertumbuhan usahanya masih sangat rendah dibandingkan dengan sektor lainnya. Sampel penelitian ditentukan dengan teknik purposive sampling sebanyak 180 pengusaha (Hair et al., 2006). Data dikumpulkan dengan kuesioner kemudian dianalisis dengan teknik analisis SEM-PLS karena lebih akurat untuk menganalisis data tentang persepsi.

\section{Hasil dan Pembahasan Hasil}

Karakteristik usaha dan pengusaha UKM di tunjukkan pada Tabel 1 sebagai berikut.

Tabel 1 Karakeritik Usaha dan Pengusaha UKM

\begin{tabular}{|c|c|c|c|c|}
\hline No & Karakteristik & Kreteria & Frekuensi & $\begin{array}{c}\text { Prosentase } \\
(\%)\end{array}$ \\
\hline \multirow[t]{2}{*}{1} & Umur Perusahaan & $4-10$ & 47 & 26,11 \\
\hline & & $10>$ & 133 & 73,89 \\
\hline \multirow[t]{2}{*}{2} & Ukuran Perusahaan & Usaha Kecil & 75 & 41,70 \\
\hline & & Usaha Menengah & 105 & 58,30 \\
\hline \multirow[t]{2}{*}{3.} & Jenis Kelamin & Laki-laki & 137 & 76,11 \\
\hline & & Perempuan & 43 & 23,89 \\
\hline \multirow[t]{2}{*}{4.} & Usia Pengusaha & $\begin{array}{ll}25 & -39 \\
40 & -49\end{array}$ & $\begin{array}{c}5 \\
77\end{array}$ & $\begin{array}{l}2,78 \\
2778\end{array}$ \\
\hline & & $50 \geq$ & 98 & 54,44 \\
\hline \multirow[t]{2}{*}{5} & Pendidikan & $<$ Sarjana & 69 & 38,3 \\
\hline & & Sarjana $\geq$ & 111 & 61,7 \\
\hline
\end{tabular}

Hasil uji model pengukuran menunjukkan semua indikator penelitian valid karena memiliki loading factors 0,5, dan nilai Average Variance Extracted (AVE) dinyatakan memuaskan karena> 0,5 serta reliabilitas konstruk dinyatakan baik dengan nilai composite reliability > 0,7. Sedangkan hasil uji model struktural (inner weight) dinyatakan sesuai/Goodness of Fit dengan koefisien R-Square $>0,5$. Hasil uji pengaruh antar variabel ditunjukkan pada Tabel 2 sebagai berikut.

Tabel 2 Pengaruh antar Variabel Penelitian

\begin{tabular}{l|c|c|c}
\hline \multicolumn{1}{c|}{ Pengaruh } & Koefisien Path & $\boldsymbol{p}$ value & Keterangan \\
\hline NS ->KP-UKM & $-0,058$ & 0.6493 & Tidak Signifikan \\
MB -> KP-UKM & 0,238 & 0,0434 & Sig.<5\% \\
NS -> MB & 0,223 & 0,1473 & Tidak Signifikan \\
\hline
\end{tabular}

Selanjutnya, mengacu pada ketentuan Barron dan Kenny (1986) bahwa motivasi berprestasi pengusaha tidak memediasi pengaruh norma subyektif pengusahaterhadap keputusan pembiayaan utangnya karena hubungan norma subyektif terhadap keputusan pembiayaan utang dan motivasi berprestasinya tidak signifikan secara statistik.

\section{Pembahasan}

Keputusan pembiayaan eksternal pengusaha UKM kerajinan di Provinsi Bali rata-rata sebesar 19,875 persen, artinya sebesar 19,87 persen dari modal yang dikelola UKM merupakan pembiayaan eksternal yang bersumber dari keluarga, teman, rekan bisnis, pemerintah, bank dan lembaga keuangan non bank yang mensyaratkan pembayaran bunga dan pokok pinjaman. Hasil penelitian ini tidak jauh berbeda dengan temuan RAM Consulting (2005) dan ICreative (2013) bahwa akses pengusaha UKM terhadap sumber pembiayaan eksternal untuk meningkatkan pertumbuhan usahanya masih rendah yaitu hanya $3-18 \%$.

Hasil penelitian ini mendukung temuan Ogarca (2010) bahwa pengusaha UKM adalah tokoh sentral dalam proses manajemen usaha kecil karena tidak ada pemisahaan yang jelas 
antara pemilik dan pengelolanya sehingga faktor pribadi pengusaha mempengaruhi keputusan pengelolaan usahanya. Berbeda dengan perusahaan besar dimana pengambilan keputusan-keputusan bisnisnya lebih rasional, bersifat formal dan kurang dipengaruhi oleh karakteristik pribadi pemiliknya (Gait dan Worthington, 2009).

Rendahnya akses pengusaha UKM kerajinan di provinsi Bali terhadap sumber-sumber pembiayaan eksternal juga menunjukkan bahwa walaupun dalam kehidupan sosial kekerabatan dan kekeluargaan masyarakat sangat tinggi namun dalam pengelolaan usahanya pengusaha sangat mandiri.Mendukung temuan studi Hill (2001), Saefuloh (2007) bahwa rendahnya akses pengusaha terhadap sumber pembiayaan eksternal karena menghindari risiko gagal dan pendapatan yang tidak pasti serta menghindari kontrol dari pihak eksternal terhadap usahanya. Padahal, pemerintah daerah baik kabupaten maupun provinsi melakukan berbagai upaya untuk mengoptimalkan peran PLUT-KUMKM dalam memberikan pelatihan dan pendampingan kepada pengusaha dalam mengelola usaha dan mengakses sumber-sumber pembiayaan eksternal namun partisipasi pengusaha untuk mengikuti proses kegiatan tersebut masih sangat rendah.

Selain itu, dilihat dari karakteristik UKM sebagian besar merupakan pengusaha menengah yaitu 105 (58,30\%), yang telah berdiri lebih dari 10 tahun sebanyak 133 (73,89\%). Kondisi ini menunjukkan bahwa ukuran dan umur perusahaan sudah cukup matang dalam pertumbuhan usahanya dan mempunyai akumulasi laba yang cukup untuk membiayai pertumbuhan usahanya. Hasil penelitian ini menunjukkan bahwa teori-teori keuangan struktur modal tidak dapat sepenuhnya diterapkan untuk menjelaskan keputusankeputusan bisnis dan pembiayaan pada UKM.

1) Norma subyektif pengusaha berpengaruh negatif dan tidak signifikan terhadap keputusan pembiayaan utang UKM. Artinya, semakin tinggi keyakinan pengusaha terhadap dukungan keluarga, teman, rekan bisnis dan pemerintah serta perilaku aktual pembiayaan utang orang-orang penting tersebut tidak dipertimbangkan dalam keputusan pembiayaanutangnya. Temuan ini mengindikasikan bahwa dalam kehidupan sosial dan sistem kekeluargaan masyarakat di Provinsi Bali sangat kental namun dalam mengelola usahanya sangat mandiri. Hasil penelitian ini mendukung temuan Saeffuloh (2007), namun bertentangan dengan Makpotche (2015), Koroppet al. (2014), bahwa norma subyektif berpengaruh dominan pada keputusan bisnis pada UKM, bila pengusaha kurang pengetahuan dan pengalaman dalam mengelola usahanya.

Norma subyektif mempengaruhi perilaku tertentu mengacu pada konsep norma subyektif Kelman (1958), yang diuji kembali oleh Venkatesh dan Davis, (2000) bahwa seseorang menerima pengaruh norma sosial melaluitiga proses yaitu:kepatuhan, identifikasi dan internalisasi. Namun, pada kontek ini, tidak ada kewajiban bagi pengusaha UKM untuk mematuhi dukungan dan tekanan orang-orang penting baginya, tidak untuk mendapatkan pengakuan dan tidak sesuai dengan tujuan pengelolaan usahanya.

2) Motivasi berprestasi pengusaha berpengaruh positif dan signifikan terhadap keputusan pembiayaan utang pengusaha UKM. Artinya,semakin tinggi motivasi berprestasi pengusaha semakin banyak mempergunakan pembiayaan utang. Hasil penelitian ini mendukung Collin et al.(2004), Wang et al. (2006), Shepherd dan Wiklund (2005) bahwa motivasi berprestasi pengusaha yang tinggi untuk mencapai keuntungan financial cenderung lebih banyak mempergunakan pembiayaan utang dan penggunaan pembiayaan utang mendorong pengusaha mengelola usahanya dengan lebih baik, giat dan efisien. Berbeda dengan pengusaha dengan motivasi mengelola usaha untuk gaya hidup, cenderung lebih mengutamakan control terhadap bisnisnya, menghindari ketergantungan dengan pihak lain dengan mengurangi penggunaan sumber-sumber pembiayaan utang. Perilaku-perilaku tersebut tercermin dalam pilihan struktur modalnya.

3) Norma subyektif pengusaha berpengaruh positif tetapi tidak signifikan terhadap motivasi berprestasi pengusaha UKM. Artinya, semakin tinggi norma subyektif pengusaha semakin tinggi motivasi berprestasi pengusaha UKM. Temuan ini menunjukkan bahwa pengusaha menyetujui pentingnya dukungan orang-orang penting baginya dan perilaku aktual orang-orang penting tersebut dalam membiayai usahanya namun tidak 
dipertimbangkan dalam mengambil keputusan utang. Selain itu, temuan ini mengindikasikan bahwa dalam segala aspek kehidupan sosial, kekerabatan dan sikap hidup bergotong royong masyarakat di Provinsi Bali sangat tinggi namun, dalam berbisnis dan mengelola usahanya pengusaha UKM cukup mandiri. Temuan ini mengindikasikan bahwa pengusaha dengan motivasi berprestasi yang tinggi cenderung menghindari dan mengabaikan dukungan dan tekanan dari pihak eksternal. Hasil penelitian ini berbeda dengan temuan Taorminadanlao (2007), Culkindan Smith (2000), LeCornuet al. (1996) bahwa norma-norma social mempengaruhi motivasi berprestasi pengusaha dalam mengelola usahanya dan menentukan kesukses bisnis pada UKM.

4) Motivasi berprestasi tidak memediasi pengaruh norma subyektif terhadap keputusan pembiayaan utang UKM. Artinya, motivasi berprestasi tidak berperan dalam meningkatkan pengaruh norma subyektif pengusaha terhadap keputusan pembiayaan utangnya. Keyakinan pengusaha terhadap dukungan dari orang-orang penting baginya dan perilaku aktual pembiayaan usaha orang-orang penting tersebut tidak mempenngaruhi motivasi berprestasi dan keputusan utang UKM. Motivasi berprestasi tidak berperan memediasi pengaruh norma subyektif terhadap keputusan pembiayaan utang UKM karena sebagian besar pengusaha UKM di Provinsi Bali berpendidikan sarjana dan bahkan pasca sarjana, berumur lebih dari 50 tahun, mengelola usaha menengah yang telah berdiri lebih dari 10 tahun. Hal ini menunjukkan pengusaha sudah cukup berpengalaman dalam mengatasi berbagai permasalahan dalam mengelola usahanya sehingga cenderung mengabaikan peran norma subyektifnya.

Hasil penelitian ini bertentangan dengan temuan Culkindan Smith (2000), (Wengeldan Rodriguez, 2006) bahwa motivasi berprestasi memiliki arti penting dalam perkembangan individu dan kemajuan sosial karena itu pengusaha UKM perlu menciptakan dan beroperasi pada lingkugan sosial yang positif dan harmonis karena pertumbuhan usaha dapat dicapai bila lingkungan sosial dapat diprediksi dan mendukung pertumbuhan usaha tersebut

\section{Simpulan dan Saran}

Norma subyektif tidak berpengaruh terhadap keputusan pembiayaan utang UKM, 2) Motivasi berprestasi pengusaha berpengaruh positif dan signifikan terhadap keputusan pembiayaan utang, 3) Norma subyektif pengusaha tidak berpengaruh terhadap motivasi berprestasi pengusaha,4) Motivasi berprestasi pengusaha tidak memediasi pengaruh norma subyektif pengusaha terhadap keputusan pembiayaan utang UKM. Perlu ngembangan program pembinaan lingkungan sosial yang tepat untuk mendorong pengusaha mengakses sumber-sumber pembiayaan utang dalam meningkatkan pertumbuhan usahanya. Penelitian lanjutan disarankan menguji pengaruh triadic antar variabel sehingga temuan dapat mengungkap secara utuh bagaimana aspek pribadi dan lingkungan saling mempengaruhi dalam menentukan perilaku pengusaha UKM.

\section{Daftar Pustaka}

Abdulwahab,MuradHusni danAl-Damen , Rula Ali. 2015 The Impact of Entrepreneurs' Characteristics on Small Business Success at Medicallnstruments Supplies Organizations in Jordan International Journal of Business and Social Science Vol. 6, No. 8

Alleyne, P. dan Tracey, B., 2011, Using the Theory of Planned Behaviour and Risk Propensity to Measure Investment Intentions among Future Investors, Journal of Eastern Caribbean Studies, Vol. 36

Baron, R.M., dan Kenny, D.A. 1986. Themoderator-mediator variable distinction in social psychological research:Conceptual, strategic, and statisticalconsiderations. Journal of Personalityand Social Psychology, 51(6), 1173-1182. 
Collins, Christopher J. Hanges, Paul J. dan Locke, Edwin A. 2004. The Relationship of Achievement Motivation to Entrepreneurial Behavior: A Meta-AnalysisCornell University ILR School Digital Commons@ILR

Chartier, M.J., Walker, J.R., danNaimark, B.2009.Health risk behaviors and mental health problems as mediatorsof the relationship between childhood abuse and adult health. AmericanJournal of Public Health, 99(5), 847-854.

Crothers, L. M., Hughes, T. L., danMorine, K. A. 2008. Theory and cases in school-based consultation:A resource for school psychologists, school counselors, special educators, and other mental health professionals . New York: RoutledgeTaylor \& Francis Group.

Culkin, N., \& Smith, D. 2000. An emotional business: A guide tounderstanding the motivations of small business decision takers. Qualitative Market Research, 3(3), 145157.

Fishbein, M. danAjzen, I., 1975, Belief, Attitude, Intention and Behavior: An Introduction to Theory dan Research, London, Addison-Wesley Publishing Company.

Guay, F., Chanal, J., Ratelle, C. F., Marsh, H. W., Larose, S., danBoivin, M. 2010. Intrinsic, identified, and controlled types of motivation for school subjects in young elementary school children. British Journal of Educational Psychology, 80(4), 711-735.

Halim, Fatimah Wati Dan Zainal, Arifin. 2015. Achievement Motivation As Mediating Factor In The Relationship Between Personality And Job Performance Relationship Journal Of Social Sciences And Humanities

Hair, Joseph F., William C. Black, Barry J. Babin, Rolph E. Anderson, dan Ronald L. Tatham, 2006, Multivariate Data Analysis, Sixth Edition, New Jersey: Pearson Prentice Hall

Koestner, R. dan McClelland, D.C. 1990. Perspectives on competence motivation. DIm. Pervin, L.A. (pnyt.). Handbook of Personality:Theory and Research, hlm. 527-548. New York:Guilford.

Kelman, H.C., 1958, Complience, Identification and Internalization: Three Processes of attitude Change?,Journal of Conflict Resolution 2, pp 51-60.men in Greece,.

Koropp, Christian., Kellermanns ,Franz W., Grichnik, Dietmar, and Stanley, Laura. 2014. Financial Decision Making in Family Firms: An Adaptation of the Theory of Planned Behavior. Family Business Review1-21

Lecornu, M. R., McMahon, R. G. P., Forsaith, D. M. and Stanger, A. M. J. (1996), The smallenterprise financial objective function. Journal of Small Business Management, 34 (3): 1-14.

MacKinnon, D.P. (2012). Introduction tomediation analysis: Importance, applications, and examples. Paper presentedat the Causality Symposium 2012,Jena, Germany.

Makpotche, Marcellin., Logossah, Kinvi., Amewokunu, Yao., Lawson-Body, Assion., and Sedzro, Komlan. 2015 Impact of Cultural Beliefs on Entrepreneurs' Intention to use Bank Loans. Journal of Applied Finance \& Banking, vol. 5, no. 4, 2015, 11-32 ISSN: $1792-6580$

Mac AnBhaird, C., danLucey, B. 2010. Determinesof capital structure in Irish SMEs. Small Business Economics 
Mustikarini, Carolina Novi, Setyawati, Christina YanitaSetyawati Gunawan, Inge. 2013. Mediating Role Of Intrinsic MotivationOn The Relationship Between Cognitive Aspects AndCreative Behaviour Of Young Entrepreneurs In Surabaya. 13thAnnual SEAAIR Conference Jogjakarta • Indonesia

Setia-Atmaja, L., Tanewski, G. A., dan Skully, M. 2009. The role of dividents, debt and board structure inteh governance of family controlled firms. Journal of Business, Finance and Accounting, 36(7), 863-898.

Shepherd, D. A., dan Wiklund, J. 2005. Entrepreneurial small businesses: A resource-based perspective. Cheltenham: Edward Elgar Publishing Ltd.

Saefuloh, Asep Ahmad.2007.KebijakanPemerintahdalamPembinaanPengusaha Kecil danMenengah (StudiKasus di Provinsi Bali dan Sulawesi Utara.P3DI Sekjen DPR-RI

Thobjornsen, H., Pederson, P.E., dan Nysveen, H. 2007. This is who I am: Indentity Expressiveness and the theory of planned behavior. Psychology \& Marketing, 24 (9): 763-785

Taormina, R. J., \& Lao, S. K. M. 2007.Measuring Chinese entrepreneurial motivation: Personality and environmental influences. International Journalof Entrepreneurial Behaviour\& Research, 13(4), 200-221.

Wang, C., Walker, EA., and Redmond, J. 2006. Ownership Motivation and Strategic Planning in Small Business Journal of Asia Entrepreneurship and Sustainability Volume II, Issue 4 special issue - initiate 21, Brisbane.

Wijaya, T., 2008.Kajian Model EmpirisPerilakuBerwirausaha UKM DIY danJawa Tengah.JurnalManajemendanKewirausahaanVol 10 No 2

Wengeldan Rodriguez,.2006. SME Export Performance in I Indonesia After the Crisis Small Business Economics (2006) 26: 25-37

Wiklund, J., P. DavidssondanF.Delmar, 2003,What Do They Think and Feel about Growth? An Expectancy-Value Approach to Small Business Managers'Attitudes toward Growth, Entrepreneurship Theory and Practice 27 (3): 247-269. 